\title{
Influence of cell culture media and feed supplements on cell metabolism and quality of IgG produced in CHO-K1, CHO-S, and CHO-DG44
}

\author{
David Reinhart ${ }^{1 *}$, Lukas Damjanovic ${ }^{1}$, Wolfgang Sommeregger ${ }^{1}$, Andreas Gili², Stanislaus Schafellner ${ }^{1}$, \\ Andreas Castan ${ }^{3}$, Christian Kaisermayer ${ }^{4}$, Renate Kunert ${ }^{1}$ \\ From 24th European Society for Animal Cell Technology (ESACT) Meeting: C2P2: Cells, Culture, Patients, Products \\ Barcelona, Spain. 31 May - 3 June 2015
}

\section{Background}

Chinese hamster ovary $(\mathrm{CHO})$ cells have become the preferred expression system for the production of complex recombinant proteins. In this study, chemically defined $\mathrm{CHO}$ cell culture media and feed substrates from different vendors were investigated regarding their influence on cell metabolism, antibody titer and quality. Special emphasis was put on elucidating how these attributes change with the use of different $\mathrm{CHO}$ host cell lines. For this purpose, CHO-K1, CHO-DG44, and CHO-S - each producing the same IgG antibody - were adapted to ActiCHO ${ }^{\mathrm{TM}} \mathrm{P}$ and $\mathrm{CD} \mathrm{CHO}$ medium. All three cell lines were grown both in batch and in fedbatch cultures using the manufacturer's specific concentrated feed supplements. The impact of the different media and feeds on antibody production, cell growth, cell-specific nutrient consumption, by-product formation and IgG quality was analyzed throughout the process.

\section{Materials and methods}

CHO-K1, CHO-S and CHO-DG44 cell lines producing the same IgG were grown in two different cultivation media, ActiCHO P (GE Healthcare) and CD CHO (Life Technologies). Batch and fed-batches were performed in Erlenmeyer shake flasks (Corning, NY) in a $\mathrm{CO} 2$ incubator shaker (Kühner, Switzerland) at $37^{\circ} \mathrm{C}, 7 \% \mathrm{CO} 2,140 \mathrm{rpm}$ and $90 \%$ relative humidity. All experiments were performed in triplicates.

Fedbatches were fed with the corresponding feeds ActiCHO Feed A and Feed B (GE Healthcare),

\footnotetext{
* Correspondence: david.reinhart@boku.ac.at

'Department of Biotechnology, University of Natural Resources and Life

Sciences, Vienna, Muthgasse 11, 1190 Vienna, Austria

Full list of author information is available at the end of the article
}

EfficientFeed ${ }^{\mathrm{TM}} \mathrm{A}$ and FunctionMAX ${ }^{\mathrm{TM}}$ (both Life Technologies) according to the manufacturer's instructions [1]. The respective feeding regimens are shown in Table 1 . The residual glucose concentration was maintained above $3 \mathrm{~g} / \mathrm{L}$ by addition of glucose concentrate.

Daily, samples were drawn to determine of cell concentration, viability, IgG titer, metabolites (i.e. glucose, glutamine, glutamate, lactate, ammonium), osmolality. Additionally, on day 4 (mid-exponential growth phase), day 7 (end exponential growth phase) and at culture termination (=viability $<60 \%$ ) we analyzed residual amino acid concentrations, gene copy numbers and mRNA, intracellular product content by flow cytometry, as well as antibody quality by SDS-PAGE, Western blotting, glycosylation, product aggregation, distribution of charge variants and thermal stability.

\section{Results}

In general, fedbatch strategies considerably prolonged the process duration as compared to the batch cultures. As a consequence, higher cell peak concentrations were obtained which additionally boosted the antibody titers up to more than six-fold (data not shown).

As shown in Figure 1, the highest cell and antibody concentrations were obtained when ActiCHO P was used as basal medium for all three recombinant cell lines (CHO-K1, CHO-DG44 and CHO-S). The higher specific growth rate in ActiCHO $\mathrm{P}$ resulted in higher peak cell concentrations and an up to five-fold difference in the viable cell integral (data not shown). Up to six-fold differences in IgG titers were found between cells grown in the two media (Figure 1B). The specific rates of IgG production were in good agreement with the intracellular expression of light and heavy chain 
Table 1. Fedbatch feeding strategies

\begin{tabular}{lllll}
\hline Basal medium & ActiCHO Feed $\mathbf{A}$ & ActiCHO Feed $\mathbf{B}$ & EfficientFeed $\mathbf{A}$ & FunctionMAX \\
\hline ActiCHO P & Daily; 3\% & Daily; 0.3\% & - & - \\
CD CHO & - & - & $4,6,8 ; 10 \%$ & $4,6,8 ; 3.3 \%$ \\
\hline
\end{tabular}

The time [d] for feed addition and the feed volume in \% of the culture volume are indicated. Feed start for the culture in ActiCHO $\mathrm{P}$ was day 3.

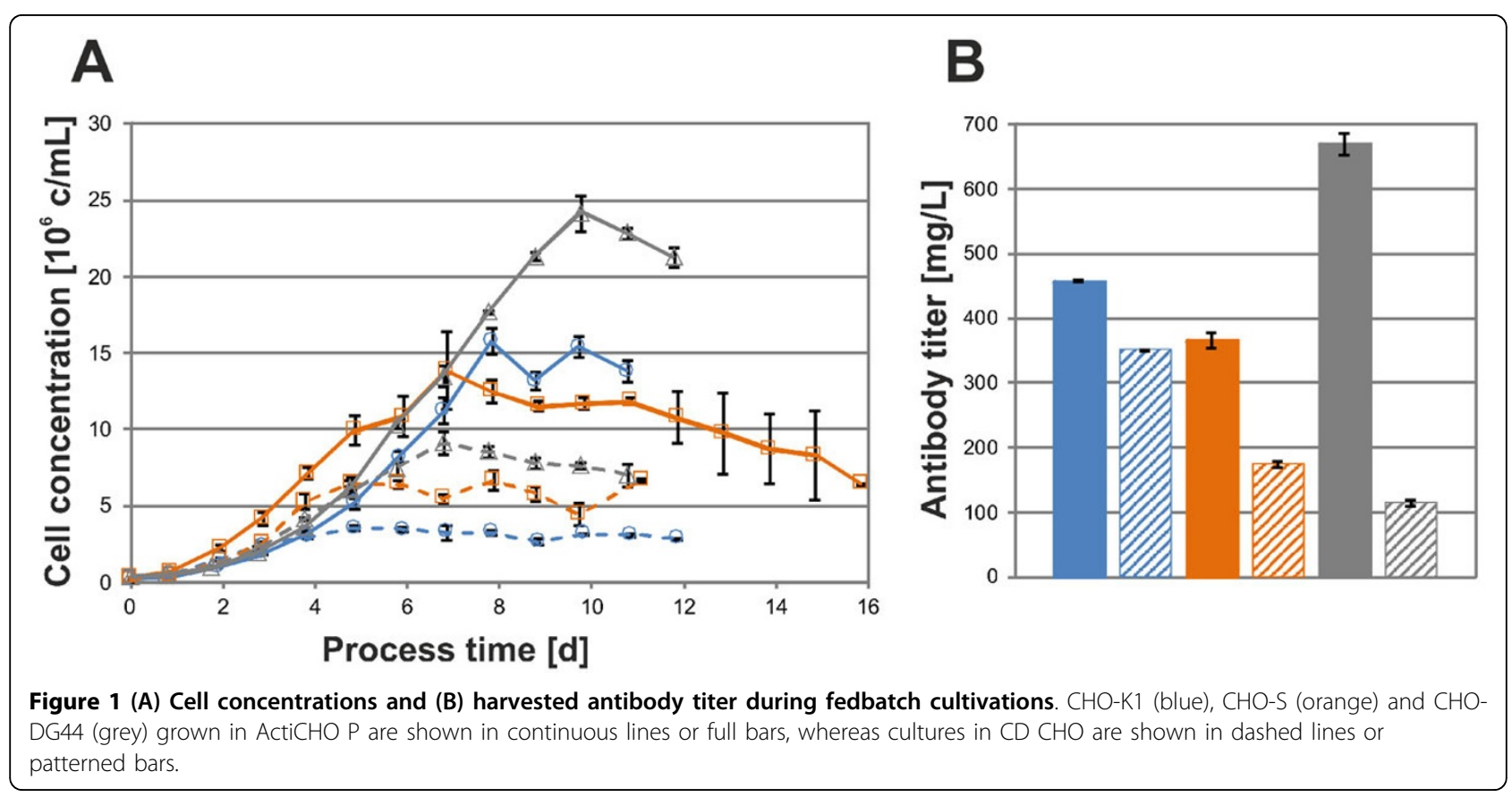

mRNA levels in all three $\mathrm{CHO}$ cell lines (data not shown). Consequently, the higher viable cell integral in ActiCHO P fed-batches was the main contributor to the higher antibody concentrations.

The two fed-batch strategies clearly influenced the cell-metabolic rates of nutrient consumption and byproduct formation (data not shown). For example, the cell-specific glucose consumption rates were 30-55\% higher in $\mathrm{CD} \mathrm{CHO}$ medium for all three $\mathrm{CHO}$ cell lines. Further, the three $\mathrm{CHO}$ cell lines converted glucose to lactate with different efficiencies. Depending on the host cell line 10-15\% (CHO-S), 25\% (CHO-DG44) and 40\% $\mathrm{CHO}-\mathrm{K} 1$ of glucose was converted to lactate. Glutamine, a major energy source for $\mathrm{CHO}$ cells, was consumed at comparable cell-specific rates in both media. Moreover, the cell-specific rates of glutamine consumption were determined to be highly host cell line-specific. Another remarkable finding was that all cell lines revealed a net consumption of glutamine in $\mathrm{CD} \mathrm{CHO}$ fed-batches, whereas a net production was observed in ActiCHO P cultures. This finding may influence the design of future feeding strategies. The specific rates of ammonium production were not altered by the medium for CHO-K1. However, 30-60\% lower values were obtained when
CHO-S and CHO-DG44 were grown in ActiCHO P fedbatches.

The harvested cell culture supernatant of all triplicate fed-batch cultures was purified and subsequently analyzed for antibody quality by different techniques. All samples appeared homogeneous, pure and of correct molecular weight on an SDS-PAGE and the amount of aggregated product was less than $5 \%$ as determined by SEC (data not shown).

Glycosylation of the antibody's Fc domain was alternated in response to the usage of $\mathrm{CHO}$ cell line as well as feeding strategy (data not shown). Generally, higher levels of fucosylation were determined for $\mathrm{CHO}-\mathrm{S}$ cultures as well as fed-batches in $\mathrm{CD}$ CHO. IgG produced by $\mathrm{CHO}-\mathrm{S}$ and $\mathrm{CHO}-\mathrm{K} 1$ had higher levels of galactosylation when cultivated in ActiCHO P, whereas the CHO-DG44 cell line was not affected by the feeding strategy. Mannose structures were most efficiently processed (=lowest high-mannose structures) in $\mathrm{CHO}-\mathrm{S}$, followed by CHO-K1 and CHO-DG44.

\section{Conclusions}

The medium highly affected the bioproduction process and yielded in up to five-fold higher peak cell and in up 
to six-fold higher antibody titers. Also the cell-metabolic rates (i.e. glucose and glutamate) were influenced by the production medium. Lactate production and cell-specific rates of glutamine consumption highly depended on the $\mathrm{CHO}$ host cell line. Regarding product quality, the choice of medium and $\mathrm{CHO}$ host cell line both can be used to fine-tune antibody glycosylation such as fucosylation, galactosylation and mannosylation.

\section{Acknowledgements}

We thank GE Healthcare and Polymun Scientific

ImmunbiologischeForschung for funding this study.

\section{Authors' details}

'Department of Biotechnology, University of Natural Resources and Life Sciences, Vienna, Muthgasse 11, 1190 Vienna, Austria. ${ }^{2}$ Polymun Scientific Immunbiologische Forschung GmbH, Donaustraße 99, 3400 Klosterneuburg, Austria. ${ }^{3} \mathrm{GE}$ Healthcare Bio-Sciences AB, Björkgatan 30, 75184 Uppsala, Sweden. ${ }^{4}$ BioMarin International Limited, Shanbally, Ringaskiddy, County Cork, Ireland.

Published: 14 December 2015

\section{Reference}

1. Barrett S, Boniface R, Dhulipala P, Slade P, Tennico Y, Stramaglia M, Lio P, Gorfien SF: Attaining next-level titers in $\mathrm{CHO}$ fed-batch cultures. BioProcess International 2012, 10:56-62.

doi:10.1186/1753-6561-9-S9-P36

Cite this article as: Reinhart et al: Influence of cell culture media and feed supplements on cell metabolism and quality of IgG produced in CHO-K1, CHO-S, and CHO-DG44. BMC Proceedings 2015 9(Suppl 9):P36.

\section{Submit your next manuscript to BioMed Central} and take full advantage of:

- Convenient online submission

- Thorough peer review

- No space constraints or color figure charges

- Immediate publication on acceptance

- Inclusion in PubMed, CAS, Scopus and Google Scholar

- Research which is freely available for redistribution

Submit your manuscript at www.biomedcentral.com/submit
Ciomed Central 